\title{
Anticipating resistance to KRAS inhibition: a novel role for USP21 in macropinocytosis regulation
}

\author{
Howard C. Crawford \\ Henry Ford Pancreatic Cancer Center, Henry Ford Health System, Detroit, Michigan 48202, USA
}

Pancreatic ductal adenocarcinoma (PDAC) is one of the deadliest cancers. Virtually all PDAC harbors an oncogenic mutation in the KRAS gene, making it the prime target for therapy. Most previous attempts to inhibit KRAS directly have been disappointing, but recent success in targeting some KRAS mutants presages a new era in PDAC therapy. Models of PDAC have predicted that identifying KRAS inhibitor resistance mechanisms will be critical. In this issue of Genes \& Development, Hou and colleagues (pp. 1327-1332) identify one such mechanism in which the deubiquitinase USP21 up-regulates the nutrient-scavenging process of macropinocytosis, rescuing PDAC cells from Kras extinction.

Pancreatic ductal adenocarcinoma (PDAC) is the most common form of pancreatic cancer and the third most deadly cancer in the United States (Siegel et al. 2021). Very little progress has been made in treating PDAC over the past several decades, due in part to most cases presenting as metastatic disease upon diagnosis and its resistance to conventional and targeted therapies. Its relatively homogenous mutational landscape, including oncogenic mutation of $K R A S$, found in virtually all cases of PDAC, together with inactivation of tumor suppressor genes such as TRP53, CDKN2A, and SMAD4, has facilitated the development of some of the most useful preclinical mouse models of any tumor type (Hingorani et al. 2005; Ying et al. 2012). Among other things, these mouse models have confirmed that mutant Kras (Kras*) is sufficient to initiate transformation in the pancreas and that extinguishing $\mathrm{Kras}^{*}$ expression after progression to adenocarcinoma leads to widespread tumor regression (Ying et al. 2012), indicating that, even in these later stages, pancreatic tumor cells remain addicted to constitutive Kras* signaling, reinforcing its status as the prime therapeutic target in the treatment of PDAC.

[Keywords: KRAS; MARK3; USP21; macropinocytosis; targeted therapy resistance]

Corresponding author: hcrawfo1@hfhs.org

Article is online at http://www.genesdev.org/cgi/doi/10.1101/gad.348971. 121.
Unfortunately, KRAS* has long been considered "undruggable" for a variety of reasons. That status changed very recently with the development of small molecules that specifically target the G12C KRAS* protein, which has shown clinical efficacy (Herdeis et al. 2021). However, this specific KRAS mutation is found in only a small fraction $(\sim 1 \%)$ of human PDACs compared with G12D (41\%), G12V (34\%), or G12R (16\%) (Waters and Der 2018). Fortunately, small molecules that target some of these more common KRAS mutants are in development (Herdeis et al. 2021), giving hope for the future of effective treatment of the vast majority of PDAC patients.

With viable KRAS inhibitors finally making headway, anticipating mechanisms of resistance to Kras inhibition is paramount. Indeed, while extinguishing Kras* expression in PDAC mouse models causes tumor regression, resistant tumors do arise over time. In previous studies, DePinho and colleagues (Kapoor et al. 2019) have found that up-regulation of the Hippo pathway transcription factor, YAP1, is one mechanism that compensates for loss of Kras* activity in $\sim 30 \%$ of resistant tumors examined. In a subsequent study, the same group used a gain-of-function screen using a library encoding 284 epigenetic regulators, leading to the identification of HDAC5 expression as sufficient to compensate for the loss of Kras* by modifying the inflammatory tumor microenvironment (Hou et al. 2020).

This prior epigenetic regulator screen revealed several additional suspects that had the potential to help PDAC overcome its Kras* addiction. The second most prominent hit was Usp21, a deubiquitinase that is amplified and overexpressed in $20 \%$ of PDAC patient samples (Hou et al. 2019). USP21 is best known for its nuclear function as a histone deubiquitinase, although nuclear USP21 promotes pancreatic tumor growth by deubiquitinating the transcription factor TCF7, amplifying canonical Wnt signaling, and enhancing tumor stem cell properties (Hou et al. 2019). In the current study, Hou

(C) 2021 Crawford This article is distributed exclusively by Cold Spring Harbor Laboratory Press for the first six months after the full-issue publication date (see http://genesdev.cshlp.org/site/misc/terms.xhtml). After six months, it is available under a Creative Commons License (Attribution-NonCommercial 4.0 International), as described at http://creativecommons.org/licenses/by-nc/4.0/. 
et al. (2021) present an elegant, textbook example of scientific sleuthing to uncover a novel mechanism behind USP21's ability to overcome the loss of Kras* activity.

Using mutant forms of USP21 that enforce localization to the nucleus or the cytoplasm, the investigators make the surprising discovery that the relevant Kras*-bypassing activity occurs in the cytoplasm, rather than in the nucleus. USP21 did not break cells free of Kras* dependency through a straightforward reactivation of pathways downstream from Kras*, as MEK/ERK signaling remained low, nor was it associated with up-regulation of Yap activity, a previously identified mechanism of Kras* escape. Using transcriptomic analysis, the investigators discovered that USP21 overexpression up-regulates mTOR-associated signaling, with metabolomic analysis revealing an association with increased amino acid levels, a known activator of mTOR. Sifting through the usual suspects that could be responsible for this increase in amino acids, the investigators found no associated up-regulation of de novo amino acid biosynthesis, no reduction in protein translation, and no alterations in amino acid transporter expression. They also did not find an association with the breakdown of intracellular proteins, as USP21 activity decreased autophagosome formation and autophagy. Having systematically eliminated each of these candidate activities, one remained: macropinocytosis, a mechanism of nutrient scavenging that is critical for Kras mutant PDAC cell survival. Indeed, USP21 expression restored macropinocytosis in Kras*-extinguished cells, and macropinocytosis inhibitors thwarted USP21-induced Kras* escape.

Finally, to identify the direct target of USP21 activity, the investigators used the protein as bait to capture a single interacting culprit: MARK3, a microtubule-binding kinase and regulator of microtubule dynamics (Sandí et al. 2017). Closing the case, the investigators confirmed that MARK3 is deubiquitinated by USP21 and is necessary and sufficient for Kras*-independent growth, tumor formation, and macropinocytosis, with the latter being necessary for Mark3-induced tumor growth.

With their collective studies (Hou et al. 2019), together with USP21 ablation in mice having no obvious deleterious effects (Pannu et al. 2015), the investigators have made a compelling case for USP 21 as a viable therapeutic target in PDAC, either on its own or in combination with KRAS* inhibition. However, as with any compelling story, some mysteries remain. For instance, the original impetus for exploring the role of USP21 was its amplification in a significant number of pancreatic cancers (Hou et al. 2019). Would its overcoming the metabolic stress caused by KRAS* inhibition be limited to these USP21-amplified tumors, or is USP21 amplification itself indicative of an adaptive mechanism that deploys when cells are faced with such stress? It would also be fascinating to explore how the cytoplasmic and nuclear functions of USP21 may complement one another, or even synergize. Finally, the finding that MARK3 is required for macropinocytosis in this system is itself a novel discovery. If it is required for macropinocytosis in general, it also may qualify as a novel therapeutic target for treating PDAC. These and other questions will likely be answered in fu- ture studies. In the interim, while the case of effective KRAS* inhibitors is being cracked, the more mechanisms of resistance to the loss of $K R A S^{*}$ activity that are identified, the better prepared we will be to defeat this devastating and deadly disease once and for all.

\section{Acknowledgments}

Special thanks to Dr. Cosimo Commisso and Dr. Marina Pasca di Magliano for critical reading of the manuscript. H.C.C. is supported by National Cancer Institute grants R01 CA247516 and U01 CA2241145.

\section{References}

Herdeis L, Gerlach D, McConnell DB, Kessler D. 2021. Stopping the beating heart of cancer: KRAS reviewed. Curr Opin Struct Biol 71: 136-147. doi:10.1016/j.sbi.2021.06.013

Hingorani SR, Wang L, Multani AS, Combs C, Deramaudt TB, Hruban RH, Rustgi AK, Chang S, Tuveson DA. 2005. Trp53R172H and KrasG12D cooperate to promote chromosomal instability and widely metastatic pancreatic ductal adenocarcinoma in mice. Cancer Cell 7: 469-483. doi:10.1016/j .ccr.2005.04.023

Hou P, Ma X, Zhang Q, Wu CI, Liao W, Li J, Wang H, Zhao J, Zhou $\mathrm{X}$, Guan C, et al. 2019. USP21 deubiquitinase promotes pancreas cancer cell stemness via Wnt pathway activation. Genes Dev 33: 1361-1366. doi:10.1101/gad.326314.119

Hou P, Kapoor A, Zhang Q, Li J, Wu CJ, Li J, Lan Z, Tang M, Ma X, Ackroyd JJ, et al. 2020. Tumor microenvironment remodeling enables bypass of oncogenic KRAS dependency in pancreatic cancer. Cancer Discov 10: 1058-1077. doi:10.1158/21598290.CD-19-0597

Hou P, Ma X, Yang Z, Zhang Q, Wu C-J, Li J, Tan L, Yao W, Yan L, Zhou X, et al. 2021. USP21 deubiquitinase elevates macropinocytosis to enable oncogenic KRAS bypass in pancreatic cancer. Genes Dev (this issue). doi:10.1101/gad.348787.121

Kapoor A, Yao W, Ying H, Hua S, Liewen A, Wang Q, Zhong Y, Wu CJ, Sadanandam A, Hu B, et al. 2019. Yap1 activation enables bypass of oncogenic Kras addiction in pancreatic cancer. Cell 179: 1239. doi:10.1016/j.cell.2019.10.037

Pannu J, Belle JI, Förster M, Duerr CU, Shen S, Kane L, Harcourt K, Fritz JH, Clare S, Nijnik A. 2015. Ubiquitin specific protease 21 is dispensable for normal development, hematopoiesis and lymphocyte differentiation. PLoS One 10: e0117304. doi:10.1371/journal.pone.0117304

Sandí MJ, Marshall CB, Balan M, Coyaud E, Zhou M, Monson DM, Ishiyama N, Chandrakumar AA, La Rose J, Couzens $\mathrm{AL}$, et al. 2017. MARK3-mediated phosphorylation of ARHGEF2 couples microtubules to the actin cytoskeleton to establish cell polarity. Sci Signal 10: eaan3286. doi:10.1126/ scisignal.aan3286

Siegel RL, Miller KD, Fuchs HE, Jemal A. 2021. Cancer statistics, 2021. CA Cancer I Clin 71: 7-33. doi:10.3322/caac .21654

Waters AM, Der CJ. 2018. KRAS: The critical driver and therapeutic target for pancreatic cancer. Cold Spring Harb Perspect Med 8: a031435. doi:10.1101/cshperspect.a031435

Ying H, Kimmelman AC, Lyssiotis CA, Hua S, Chu GC, FletcherSananikone E, Locasale JW, Son J, Zhang H, Coloff JL, et al. 2012. Oncogenic Kras maintains pancreatic tumors through regulation of anabolic glucose metabolism. Cell 149: 656670. doi:10.1016/j.cell.2012.01.058 


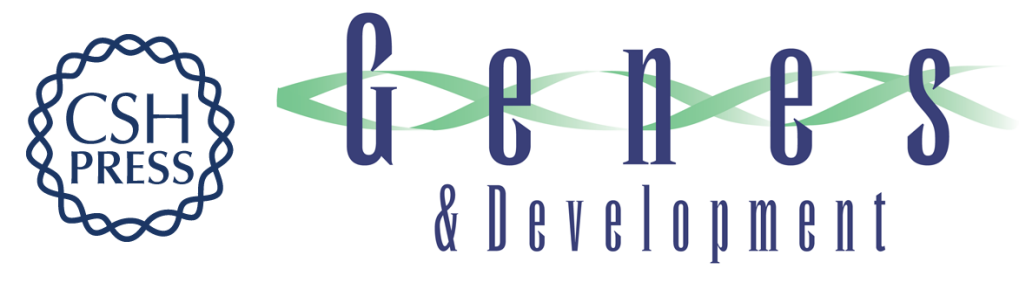

\title{
Anticipating resistance to KRAS inhibition: a novel role for USP21 in macropinocytosis regulation
}

\author{
Howard C. Crawford
}

Genes Dev. 2021, 35:

Access the most recent version at doi:10.1101/gad.348971.121
Related Content USP21 deubiquitinase elevates macropinocytosis to enable oncogenic KRAS bypass in pancreatic cancer
Pingping Hou, Xingdi Ma, Zecheng Yang, et al.
Genes Dev. October , 2021 35: 1327-1332
References This article cites 11 articles, 5 of which can be accessed free at:
http://genesdev.cshlp.org/content/35/19-20/1325.full.html\#ref-list-1
Articles cited in:
http://genesdev.cshlp.org/content/35/19-20/1325.full.html\#related-urls
Creative This article is distributed exclusively by Cold Spring Harbor Laboratory Press for the first
Commons
License
six months after the full-issue publication date (see
http://genesdev.cshlp.org/site/misc/terms.xhtml). After six months, it is available under a Creative Commons License (Attribution-NonCommercial 4.0 International), as described at http://creativecommons.org/licenses/by-nc/4.0/.
Email Alerting Receive free email alerts when new articles cite this article - sign up in the box at the top Service right corner of the article or click here.

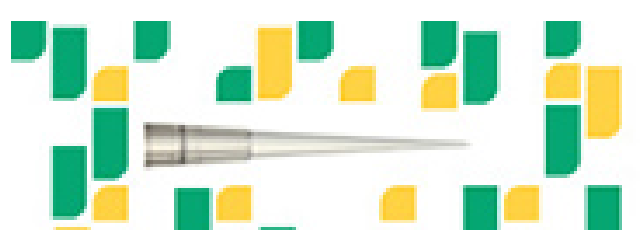

Focused on your science. 